DOI: http://dx.doi.org/10.24093/awejtls/vol2no3.7

Pp.102 -109

\title{
Joyce's Dubliners (1914) and A Portrait of the Artist as a Young Man (1916): A Postcolonial Analysis
}

\author{
Samir Ferhi \\ English Department \\ Faculty of Letters and Languages, University of Mouloud Mammeri \\ Tizi Ouzou, Algeria \\ Bouteldja Riche \\ English Department \\ Faculty of Letters and Languages, University of Mouloud Mammeri \\ Tizi Ouzou, Algeria
}

\begin{abstract}
This research paper explores James Joyce's imagined attitudes towards the building up of an Irish cultural identity and a new Irish nation in selected short stories from Dubliners (1914) and his autobiography A Portrait of the Artist as a Young Man (1916). Taking our bearing from Postcolonial theory proposed by Frantz Fanon in his The Wretched of the Earth (1968), we argue that Joyce opposes the nationalism of the literary, political, cultural, religious, and linguistic discourses advocated either by the Irish Revivalist authors such as William Butler Yeats, Lady Gregory, Edward Martyn, John Millington Synge and others, or the Gaelic League's aspirations to de-anglicise the Irish minds at the turn of the nineteenth century Dublin. Indeed, we demonstrate that according to Joyce the cultural and political nationalism vindicated by the Revivalists was old-fashioned and needed to be adapted to modern concerns. We also showed that he considers the Leaguers as 'Gaelo-centric' because of their linguistic confinement. This is why he promotes the use of an English language which is more adequate with opening Ireland for the rest of the world. What comes of this study is that Joyce plays the role of an awakener of his fellow Irish men and women and avoids falling in the traps of what Fanon (1968) calls the "pitfalls of national consciousness".
\end{abstract}

Key Words: Discourse, identity, Irish revivalism, native intellectual- subjectivity

Cite as: Ferhi, S., \& Bouteldja, R. (2018). James Joyce's Dubliners (1914) and A Portrait of the Artist as a Young Man (1916): A Postcolonial Analysis. Arab World English Journal for Translation \& Literary Studies, 2 (3). DOI: http://dx.doi.org/10.24093/awejtls/vol2no3.7 